\title{
TOTAL NONDIALYZABLE SOLIDS (TNDS) IN HUMAN URINE. II. A METHOD FOR REPRODUCIBLE FRACTIONATION ${ }^{1}$
}

\author{
By W. H. BOYCE, J. S. KING, JR., J. M. LITTLE, AND C. ARTOM \\ (From the Departments of Urology, Biochemistry, Physiology, and Pharmacology, The Bow- \\ man Gray School of Medicine, Wake Forest College, Winston-Salem, N. C.)
}

(Submitted for publication June 16, 1958; accepted July 24, 1958)

The amount and nature of the total nondialyzable solids (TNDS) of normal human urine have been parametrically defined (1). This report is concerned with a technique for separation of the TNDS into three reproducible primary fractions, which are suitable for subfractionation by other methods, and their composition.

\section{MATERIALS AND METHODS}

\section{Materials}

Subjects. Twelve young adult individuals (seven male, five female), who had no history or clinical evidence of renal disease or current evidence of other disease, served as subjects for this study. Each subject continued the usual daily activities and diet during the collection of three 24 hour urine specimens. Female subjects submitted specimens near the midportion of the menstrual cycle.

Membranes for ultrafiltration. The solvent for collodion membranes was prepared from analytical grade reagents by mixing $96.1 \mathrm{ml}$. absolute ethanol, $40.5 \mathrm{ml}$. diethyl ether, and $13.5 \mathrm{ml}$. glacial acetic acid. One hundred $\mathrm{ml}$. of collodion ${ }^{2}$ was then added and thoroughly mixed.

Discs of the best grade of plate glass, $15 \mathrm{~cm}$. in diameter, scratch-free, and hand-rubbed to provide a polished surface, were stored in bichromate cleaning solution. The edges of the glass plates were unbeveled. Prior to use, the plates were rinsed thoroughly with distilled water and air dried. The lint-free plate was then floated on mercury in a glass dish in a desiccator containing $75 \mathrm{ml}$. of concentrated sulfuric acid in the bottom. Exactly 12 ml. of the collodion solution was poured onto the center of the plate and allowed to dry for exactly 20 minutes in a closed desiccator. The collodion-covered disc was lifted out and slid into a vessel of distilled water. The gelled membrane floated free to the surface of the water and was transferred on a piece of filter paper for storage in distilled water saturated with thymol. The sulfuric acid was changed after preparation of each membrane.

These membranes have a " $T$ " value of 14 to $34 \mathrm{sec}$ onds, i.e., the period required for $100 \mathrm{ml}$. of distilled water

1 Supported by Mary Reynolds Babcock Foundation and Public Health Service Grants A-259 and H-2820, National Institutes of Health.

2 Analytical reagent, Mallinckrodt Chemical Works. to flow through $100 \mathrm{~cm} .^{2}$ of filtering area, at room temperature, at a differential pressure of $15 \mathrm{lbs}$. per sq. inch. They have a thickness of $100 \mu$, a dry weight of $1.4 \mathrm{mg}$. per $\mathrm{cm}^{2}$, and an average pore diameter of 20 (range. 14 to 26) $\mathrm{m} \mu .^{3}$ They are comparable in porosity to Schleicher and Schuell ultrafine filters, dense (average pore diameter, 10 to $20 \mathrm{~m} \mu$ ), but S. and S. ultrafine filters, medium (average pore diameter, 20 to $35 \mathrm{~m} \mu$ ) gave results comparable to those obtained with the membranes prepared in this laboratory.

Ultrafilters. Ultrafilters of $4 \mathrm{~L}$. capacity, having porous steel supporting plates $15 \mathrm{~cm}$. in diameter, were used.*

Methods

Fractionation and recovery. The collection and dialysis of 24 hour urine specimens was by the previously described technique (1). A $1 / 10$ aliquot was removed for TNDS determination and the remainder of the 24 hour specimen was ultrafiltered at approximately $3^{\circ} \mathrm{C}$., under a maximum pressure of 30 to $40 \mathrm{lbs}$. per sq. inch. This required about 24 hours. The solids in the ultrafiltrate were recovered by stepwise lyophilization, as previously described (1). The resultant brown powder was designated UFO (ultrafiltrate $\mathrm{O}$ ). The residue, designated $R O$ (residue $\mathrm{O}$ ), was removed from the membrane and extracted three times with five volumes of barbital-sodium barbital buffer, ionic strength $0.1 \mathrm{~N}, \mathrm{pH}$ 8.6. The veronal insoluble fraction of $R O$, recovered by centrifugation (relative centrifugal force $=1,000 \times \mathrm{G}, 20 \mathrm{~min}$ utes) and designated as $R 1$ (residue 1), was immediately suspended in distilled water and dialyzed against cold distilled water for not less than 24 hours; lyophilization yielded a white, fluffy powder. The clear, brown supernatant barbiturate buffer extracts were pooled and dialyzed against cold distilled water to remove the buffer. A fluffy, $\tan$ solid, designated $R S 1$ (residue, soluble 1) was then recovered by lyophilization of the solution.

Analytical techniques. The lyophilized fractions were analyzed for ash, calcium, phosphorus, nitrogen, "sialic acid," hexose ${ }^{5}$ and "bound" water as previously de-

${ }^{3}$ Characteristics of these membranes determined by Membranefiltergesellschaft, Goettingen, Germany, through the courtesy of Carl Schleicher and Schuell Company, Keene, N. H.

4 Filter model 4000, F. R. Hormann \& Co., Newark, N. J.

5 The differences found in the quantity of hexose present in the respective fractions, as measured by the anthrone and orcinol reactions, are the consequence of us- 
scribed (1). Qualitative spot tests (2) for various metals were made on samples of inorganic ash from each fraction. Hexosamine was determined by the following procedure. A 5 to $10 \mathrm{mg}$. sample in $2 \mathrm{ml}$. of water was placed in a $5 \mathrm{ml}$. glass ampul and $0.2 \mathrm{ml}$. of concentrated hydrochloric acid was added. The ampul was sealed and placed in boiling water for four hours. The hydrochloric acid was removed by evaporation in a current of air and the residue dissolved in water, adjusted to $\mathrm{pH}$ 9.8 with three to five drops of 1 per cent sodium hydroxide, and diluted with water to $10 \mathrm{ml}$. Aliquots were used for analysis as described by Schloss (3). The results are expressed in terms of glucosamine hydrochloride.

Hexuronic acid, expressed as glucuronic acid, was assayed by the method of DeFrates and Boyd (4). The samples were hydrolyzed in sealed ampuls with $6 \mathrm{~N}$ hydrochloric acid at $50^{\circ} \mathrm{C}$. for three hours. The absorption curve of the reaction product paralleled that of the glucuronic acid standard. The optical density of the final color was maximal after a two hour hydrolysis and was the same after two and a half, three, and three and a half hour periods of hydrolysis. The sensitivity of the method could be increased to measure concentrations of hexuronic acid of less than 1 per cent by increasing the time of incubation with naphthoresorcinol. It is important that, when some samples were assayed by the modified carbazole method $(5,6)$, values which were obtained were similar to those with the above technique. In neither of these procedures was there a measurable hydrolytic loss of glucuronic acid. However, neither the commercial chondroitin sulfate, an authentic semipurified sample of the urinary aminopolysaccharide of Di Ferrante and Rich (14), ${ }^{6}$ or a sample of the latter prepared by their technique (7) from our UFO fraction [12 per cent hexuronic acid (5)] gave a reaction with naphthore-

ing as a standard a mixture of galactose and mannose (1: 1 , by wt.). Such a standard does not adequately match the more complex, but unknown, pattern of polysaccharide content of these materials. Galactose, mannose, fucose, rhamnose and glucose are found chromatographically in each of these three fractions. The optical densities of $10 \mathrm{mg}$. per $100 \mathrm{ml}$. solutions of these sugars by the orcinol methods, measured with $1 \mathrm{~cm}$. cuvettes in the Beckman DU spectrophotometer, were $0.138,0.122$, $0.100,0.098$ and 0.026 , respectively. For $5 \mathrm{mg}$. per 100 ml. solutions, by the anthrone methods, they were 0.435 , $0.366,0.615,0.600$ and 0.710 , respectively. Obviously, the two series are roughly reversed with respect to color intensity. Since chromatography suggests that galactose and mannose are the predominant sugars in each fraction, the true values for hexose probably lie between those given for the two methods, and are nearer to those obtained by the orcinol method. The anthrone/orcinol ratio is thus an important indication of qualitative variation in hexose content, and is useful for comparison of the three fractions (Table VIII).

6 Supplied by Dr. Clayton Rich, The Rockefeller Institute for Medical Research. Sample assayed 15 per cent hexuronic acid (5), 17.4 per cent hexosamine. sorcinol under these conditions. Indeed, less than one per cent hexuronic acid was detected in a solution of 200 $\mu \mathrm{g}$. per $\mathrm{ml}$. of commercial chondroitin sulfuric acid, ${ }^{7}$ and only 32 per cent of the theoretically present amount was detectable after hydrolysis for 12 hours at $80^{\circ} \mathrm{C}$. Thus the method is not applicable to determinations of hexuronic acids present in acid mucopolysaccharides and the conjugate or conjugates measured by this method must be of another sort.

Total lipids, total phospholipids, total fatty acids and total unsaponifiable matter were determined as before (1) on material obtained by pooling equal quantities of each fraction from male and female subjects to form two pools, which were designated samples A and B. A sufficient quantity of material was thus obtained for complete lipid analysis. Total and esterified cholesterol were determined colorimetrically (8) on aliquots of the chloroform extracts, before and after precipitation of free cholesterol with digitonin. The values were corrected, assuming a light absorption for cholesterol esters 15 per cent greater than that for free cholesterol. This latter fraction was calculated as the difference between total and esterified cholesterol.

\section{RESULTS}

The TNDS from nine subjects, as determined from $1 / 10$ aliquots, gave a mean value of 505 (standard deviation \pm 105 ) mg. per 24 hours, an increase of 17 per cent above our previously reported value (1). The present collection period covered the months of September to November, whereas previous studies were from January to March.

\section{Recovery of TNDS following fractionation}

Eighty-two (range, 70 to 87) per cent of the TNDS of each subject was accounted for as the sum of $R 1, R S 1$ and UFO. One-fourth of the loss was accounted for by the entrapment of 4 to 5 per cent of the TNDS in the pores of the ultrafilter membrane. This is presumably a mixture of $R 1$ and $R S 1$, and can be determined by solution of the membranes in half and half ethanolether solution. The "bound" water content of the sum of the individual fractions averaged $21 \mathrm{mg}$. per 24 hours less than that of the TNDS. Loss of any portion of this water during the lyophilization of the fractions would appear as unrecovered TNDS in the calculations of recovery. The remainder of the loss during fractionation is prob-

\footnotetext{
${ }^{7}$ Contained 25.1 per cent hexosamine and 24.5 per cent hexuronic acid (5). General Biochemicals, Inc. This material was ultrafiltrable.
} 
ably mechanical, since none of the fractions were dialyzed after lyophilization (vide infra).

\section{Possible alterations of TNDS by the fractionation procedure}

Several experiments were designed to investigate the possibility that the separation procedure might produce alterations in TNDS such that the fractions would not accurately reflect the native state of these materials.

When clear whole urine was ultrafiltered, then dialyzed and again ultrafiltered, nothing was found on the filter membrane after the second ultrafiltration. This indicated that dialysis per se did not cause a coalescence of molecules to produce $R O$. When the urine was ultrafiltered directly, without preliminary dialysis, approximately the same $R S 1 / R O$ ratio $(0.29)$ was found as with dialyzed urine ( 0.3 to 0.4 in four large pools), a finding which suggests that the proportion of these materials in undialyzed urine is the same.

Addition to $U F O$ of sodium chloride to $0.58 \mathrm{~N}$ at $3^{\circ} \mathrm{C}$. did not induce any coalescence into nonultrafiltrable material on standing.

In another experiment, a three L. sample of whole urine was divided into three equal parts. To one was added $30 \mathrm{ml}$. of a solution containing $141 \mathrm{mg}$. $R S 1$; to the second was added $2 \mathrm{ml}$. of serum containing $169 \mathrm{mg}$. of nondialyzable material; the third was the control. These samples were fractionated as usual. After correction for the usual 18 per cent mechanical loss, the recoveries of the added $R S 1$ and serum were 76 and 89 per cent, respectively. Most of the missing $R S 1$ can be accounted for, since the added $R S 1$ was made up from lyophilized material (see below). These results suggest that there was no marked change in the solubility of either the $R S 1$ or the serum proteins, and therefore that $R 1$ is not a denaturation product of $R S 1$, or vice versa. Other evidence for this is $(a)$ the small but statistically significant chemical differences in the two fractions; $(b)$ the constancy of the $R S 1 / R O$ ratio at a given season of the year (in pooled samples from a variety of normal subjects this ratio agreed within 5 per cent); (c) the continued solubility of $R S 1$ after repeated freezings and lyophilization, in contrast to $R 1$, which becomes highly water insoluble on lyophilization; and $(d)$ in experiments to be described in detail elsewhere, various clinical conditions have been studied in which either $R 1$ or $R S 1$ was quantitatively changed, without significant alteration from normal in the other fraction.

\section{Quantitative data}

The results from analyses of the three fractions are presented in Tables I through V. The composition of each fraction is summarized in Table VI, and the 24 hour excretion rates are presented

TABLE I

Composition of veronal insoluble fraction (R1) of normal urinary TNDS,* expressed as per cent of dry weight

\begin{tabular}{|c|c|c|c|c|c|c|c|c|c|c|c|c|}
\hline \multirow[b]{2}{*}{$\begin{array}{c}\text { Subject } \\
\text { no. }\end{array}$} & \multirow[b]{2}{*}{$\begin{array}{c}\text { Dry } \\
\text { weight }\end{array}$} & \multicolumn{2}{|c|}{ Hexosamine } & \multicolumn{3}{|c|}{ Hexooe } & \multirow[b]{2}{*}{$\begin{array}{l}\text { Sialic } \\
\text { acid }\end{array}$} & \multirow[b]{2}{*}{ Ash } & \multirow[b]{2}{*}{$\begin{array}{l}\text { "Bound" } \\
\text { water }\end{array}$} & \multirow[b]{2}{*}{$\begin{array}{c}\text { Nitro- } \\
\text { gen }\end{array}$} & \multirow[b]{2}{*}{ Cat } & \multirow[b]{2}{*}{ P† } \\
\hline & & Female & Male & Anthrone & Orcinol & $\begin{array}{l}\text { Anth./ } \\
\text { Orc. }\end{array}$ & & & & & & \\
\hline $\begin{array}{r}1 \\
2 \\
3 \\
4 \\
5 \\
6 \\
7 \\
8 \\
9 \\
10 \\
11 \\
12\end{array}$ & $\begin{array}{c}8 . / 24 \text { hrs. } \\
51 \\
168 \\
72 \\
131 \\
88 \\
78 \\
137 \\
108 \\
35 \\
69 \\
88 \\
52\end{array}$ & $\begin{array}{l}3.0 \\
4.3 \\
4.0\end{array}$ & $\begin{array}{l}7.2 \\
5.2 \\
6.6 \\
6.4\end{array}$ & $\begin{array}{l}14.3 \\
11.3 \\
12.0 \\
17.3 \\
11.9 \\
15.4 \\
14.8 \\
11.2 \\
13.0\end{array}$ & $\begin{array}{r}8.1 \\
7.2 \\
7.7 \\
12.3 \\
9.6 \\
6.7 \\
6.3 \\
5.4 \\
6.9 \\
8.3 \\
9.7 \\
8.1\end{array}$ & $\begin{array}{l}1.83 \\
1.57 \\
1.56 \\
1.41 \\
1.24 \\
2.30 \\
2.35 \\
2.06 \\
1.88\end{array}$ & $\begin{array}{l}6.3 \\
2.6 \\
2.6 \\
2.5 \\
3.6 \\
0.0 \\
0.0 \\
3.5 \\
8.3 \\
0.0 \\
3.1 \\
9.7\end{array}$ & $\begin{array}{l}5.7 \\
5.8 \\
4.5 \\
5.2 \\
5.9 \\
4.7 \\
4.5 \\
3.8 \\
3.2 \\
6.1 \\
3.8\end{array}$ & $\begin{array}{l}5.3 \\
5.4 \\
8.7 \\
6.8 \\
6.7 \\
7.1 \\
5.3 \\
5.2 \\
6.0 \\
5.8 \\
6.7\end{array}$ & $\begin{array}{r}8.8 \\
9.2 \\
10.0 \\
10.4 \\
11.2 \\
11.2 \\
11.4 \\
11.4 \\
9.7 \\
10.6 \\
10.2 \\
10.1\end{array}$ & $\begin{array}{r}3.4 \\
11.5 \\
6.8 \\
8.4 \\
5.3 \\
7.1 \\
7.0 \\
6.9 \\
3.1 \\
26.0 \\
14.5\end{array}$ & $\begin{array}{r}6.7 \\
22.5 \\
24.3 \\
18.9 \\
9.3 \\
33.5 \\
31.4 \\
26.0 \\
10.2 \\
30.1\end{array}$ \\
\hline $\begin{array}{l}\text { Mean } \\
\text { S.E. mean }\end{array}$ & $\begin{array}{l}89.6 \\
11.42\end{array}$ & $\begin{array}{l}4.14 \\
0.33\end{array}$ & $\begin{array}{l}6.24 \\
0.23\end{array}$ & $\begin{array}{r}13.52 \\
0.76\end{array}$ & $\begin{array}{l}8.03 \\
0.53\end{array}$ & $\begin{array}{l}1.800 \\
0.129\end{array}$ & $\begin{array}{l}3.52 \\
0.91\end{array}$ & $\begin{array}{l}4.84 \\
0.30\end{array}$ & $\begin{array}{l}6.27 \\
0.23\end{array}$ & $\begin{array}{r}10.35 \\
0.25\end{array}$ & $\begin{array}{l}9.09 \\
2.06\end{array}$ & $\begin{array}{r}21.30 \\
3.06\end{array}$ \\
\hline
\end{tabular}

* Total nondialyzable solids.

$\dagger$ Per cent of ash. 
TABLE II

Composition of veronal soluble fraction (RS1) of normal urinary TNDS, expressed as per cent of dry weight

\begin{tabular}{|c|c|c|c|c|c|c|c|c|c|c|c|c|}
\hline \multirow[b]{2}{*}{$\begin{array}{c}\text { Subject } \\
\text { no. }\end{array}$} & \multirow[b]{2}{*}{$\underset{\text { weight }}{\text { Dry }}$} & \multicolumn{2}{|c|}{ Hexosamine } & \multicolumn{3}{|c|}{ Hexose } & \multirow[b]{2}{*}{$\begin{array}{l}\text { Sialic } \\
\text { acid }\end{array}$} & \multirow[b]{2}{*}{ Ash } & \multirow[b]{2}{*}{$\begin{array}{l}\text { "Bound" } \\
\text { water }\end{array}$} & \multirow[b]{2}{*}{$\begin{array}{c}\text { Nitro- } \\
\text { gen }\end{array}$} & \multirow[b]{2}{*}{$\mathrm{Ca}^{*}$} & \multirow[b]{2}{*}{$\mathrm{P}^{*}$} \\
\hline & & Female & Male & Anthrone & Orcinol & $\begin{array}{l}\text { Anth.l } \\
\text { Orc. }\end{array}$ & & & & & & \\
\hline & ng./24 hrs. & & & & & & & & & & & \\
\hline $\begin{array}{r}1 \\
2 \\
3 \\
4 \\
5 \\
6 \\
7 \\
8 \\
9 \\
10 \\
11 \\
12\end{array}$ & $\begin{array}{r}29 \\
65 \\
22 \\
72 \\
44 \\
124 \\
60 \\
65 \\
58 \\
64 \\
49 \\
54\end{array}$ & $\begin{array}{r}5.1 \\
3.6 \\
10.2\end{array}$ & $\begin{array}{l}5.6 \\
7.0 \\
6.3 \\
6.1\end{array}$ & $\begin{array}{r}11.9 \\
14.2 \\
10.8 \\
11.8 \\
10.9 \\
9.0 \\
18.1 \\
9.0\end{array}$ & $\begin{array}{r}9.9 \\
9.6 \\
8.1 \\
7.5 \\
8.6 \\
7.1 \\
6.4 \\
14.2 \\
6.7 \\
10.6 \\
7.7 \\
7.1\end{array}$ & $\begin{array}{l}1.20 \\
1.48 \\
1.44 \\
1.37 \\
1.54 \\
1.41 \\
1.27 \\
1.34\end{array}$ & $\begin{array}{r}6.6 \\
1.9 \\
2.4 \\
1.9 \\
5.2 \\
2.9 \\
1.6 \\
10.5 \\
9.0 \\
5.5 \\
12.4 \\
13.2\end{array}$ & $\begin{array}{l}3.3 \\
2.4 \\
5.4 \\
4.3 \\
3.4 \\
5.0 \\
8.2 \\
8.0 \\
8.3 \\
7.2 \\
9.2 \dagger\end{array}$ & $\begin{array}{r}6.6 \\
10.3 \\
12.5 \\
5.8 \\
10.3 \\
9.4 \\
8.2 \\
12.5 \\
9.6 \\
1.8 \\
6.9 \dagger\end{array}$ & $\begin{array}{r}9.1 \\
9.6 \\
9.7 \\
8.9 \\
9.7 \\
9.9 \\
10.9 \\
9.4 \\
10.7 \\
9.9 \\
9.4 \\
9.4\end{array}$ & $\begin{array}{r}12.6 \\
12.8 \\
5.3 \\
8.3 \\
5.7 \\
6.2 \\
2.8 \\
3.8 \\
2.4 \\
16.0 \\
4.1 \dagger\end{array}$ & $\begin{array}{r}7.5 \\
48.8 \\
14.4 \\
31.6 \\
22.7 \\
8.0 \\
7.3 \\
12.1 \\
1.2 \\
10.8 \\
6.7 \dagger\end{array}$ \\
\hline $\begin{array}{l}\text { Mean } \\
\text { S.E. mean }\end{array}$ & $\begin{array}{c}58.8 \\
\quad 7.34\end{array}$ & $\begin{array}{l}6.16 \\
2.23\end{array}$ & $\begin{array}{l}6.03 \ddagger \\
0.31\end{array}$ & $\begin{array}{l}11.96 \\
1.06\end{array}$ & $\begin{array}{l}8.63 \\
0.64\end{array}$ & $\begin{array}{l}1.381 \\
0.049\end{array}$ & $\begin{array}{l}6.09 \\
1.23\end{array}$ & $\begin{array}{l}5.88 \\
0.72\end{array}$ & $\begin{array}{l}8.54 \\
0.95\end{array}$ & $\begin{array}{l}9.72 \\
0.17\end{array}$ & $\begin{array}{l}7.27 \\
1.38\end{array}$ & $\begin{array}{r}15.55 \\
4.18\end{array}$ \\
\hline
\end{tabular}

* Per cent of ash.

Approximately equal weights of protein of numbers 11 and 12 combined for these determinations.

$\ddagger$ The combined mean for female and male $=6.08 \pm 0.50$ per cent.

in Table VII. The significant differences between the three fractions are summarized in Table VIII.

Two-dimensional chromatograms of the undialyzed materials, using the three previously reported solvent systems, revealed the presence in each of the three fractions of all those amino acids previously reported to be present in the TNDS (1). By this technique, it was not possible unequivocally to distinguish any one of the three frac- tions from the others. The amino acids demonstrated in these studies of course occur ubiquitously.

The previous observation (9) that males normally excrete more nondialyzable hexosamine per 24 hours than females has been confirmed in the present studies, and the increase is primarily in the UFO.

Hexuronic acid was also found predominantly

TABLE III

Composition of ultrafiltrate (UFO) fraction of normal urinary TNDS, expressed as per cent of dry weight

\begin{tabular}{|c|c|c|c|c|c|c|c|c|c|c|c|c|c|}
\hline \multirow[b]{2}{*}{$\begin{array}{l}\text { Subject } \\
\text { no. }\end{array}$} & \multirow[b]{2}{*}{$\begin{array}{c}\text { Dry } \\
\text { weight }\end{array}$} & \multirow{2}{*}{$\begin{array}{l}\text { Hexu- } \\
\text { ronic } \\
\text { acid }\end{array}$} & \multicolumn{2}{|c|}{ Hexosamine } & \multicolumn{3}{|c|}{ Hexose } & \multirow[b]{2}{*}{$\begin{array}{l}\text { Sialic } \\
\text { acid }\end{array}$} & \multirow[b]{2}{*}{ Ash } & \multirow[b]{2}{*}{$\begin{array}{l}\text { "Bound" } \\
\text { water }\end{array}$} & \multirow[b]{2}{*}{$\begin{array}{c}\text { Nitro- } \\
\text { gen }\end{array}$} & \multirow[b]{2}{*}{$\mathrm{Ca}^{*}$} & \multirow[b]{2}{*}{ P* } \\
\hline & & & Female & Male & $\begin{array}{c}\text { An- } \\
\text { throne }\end{array}$ & $\begin{array}{l}\text { Orci- } \\
\text { nol }\end{array}$ & $\begin{array}{l}\text { Anth./ } \\
\text { Orc. }\end{array}$ & & & & & & \\
\hline $\begin{array}{r}1 \\
2 \\
3 \\
4 \\
5 \\
6 \\
7 \\
8 \\
9 \\
10 \\
11 \\
12\end{array}$ & $\begin{array}{c}\text { ng./24 hrs. } \\
221 \\
189 \\
208 \\
217 \\
246 \\
200 \\
146 \\
259 \\
522 \\
324 \\
360 \\
292\end{array}$ & $\begin{array}{l}1.2 \\
1.1 \\
1.4 \\
1.7 \\
0.8 \\
1.4 \\
0.8 \\
2.8 \\
2.2 \\
0.9 \\
0.8 \\
0.8\end{array}$ & $\begin{array}{l}9.5 \\
9.8 \\
6.6\end{array}$ & $\begin{array}{r}8.3 \\
7.0 \\
10.6 \\
10.9\end{array}$ & $\begin{array}{l}27.4 \\
39.3 \\
21.0 \\
20.6 \\
18.5 \\
17.4 \\
18.7 \\
12.4 \\
19.0\end{array}$ & $\begin{array}{l}15.9 \\
16.4 \\
16.6 \\
18.5 \\
15.1 \\
13.6 \\
14.6 \\
13.2 \\
13.5 \\
11.8 \\
18.6 \\
14.6\end{array}$ & $\begin{array}{l}1.72 \\
2.40 \\
1.27 \\
1.11 \\
1.23 \\
1.28 \\
1.28 \\
0.94 \\
1.41\end{array}$ & $\begin{array}{r}11.0 \\
7.1 \\
8.5 \\
8.8 \\
13.2 \\
8.3 \\
12.5 \\
9.7 \\
12.3 \\
8.7 \\
14.9 \\
11.6\end{array}$ & $\begin{array}{l}20.8 \\
21.4 \\
22.2 \\
18.9 \\
14.8 \\
24.0 \\
22.2 \\
30.9 \\
20.2 \\
16.4 \\
16.9 \\
18.2\end{array}$ & $\begin{array}{r}7.5 \\
6.7 \\
5.7 \\
7.3 \\
8.4 \\
7.4 \\
8.6 \\
6.6 \\
9.1 \\
7.9 \\
10.1 \\
8.2\end{array}$ & $\begin{array}{l}6.1 \\
5.2 \\
4.8 \\
5.3 \\
5.8 \\
4.6 \\
6.1 \\
4.5 \\
9.2\end{array}$ & $\begin{array}{r}6.1 \\
12.1 \\
12.8 \\
11.8 \\
8.0 \\
12.0 \\
10.6 \\
8.3 \\
5.0 \\
11.5 \\
10.4 \\
9.0\end{array}$ & $\begin{array}{r}5.4 \\
3.6 \\
4.5 \\
3.7 \\
9.0 \\
5.2 \\
6.2 \\
10.2 \\
11.2 \\
8.5 \\
5.7 \\
7.6\end{array}$ \\
\hline $\begin{array}{l}\text { Mean } \\
\text { S.E. mean }\end{array}$ & $\begin{array}{c}264.5 \\
29.17\end{array}$ & $\begin{array}{l}1.33 \\
0.18\end{array}$ & $\begin{array}{l}8.66 \\
0.59\end{array}$ & $\begin{array}{c}10.41 \dagger \\
0.77\end{array}$ & $\begin{array}{r}21.59 \\
2.57\end{array}$ & $\begin{array}{r}15.20 \\
0.60\end{array}$ & $\begin{array}{l}1.40 \\
0.14\end{array}$ & $\begin{array}{r}10.55 \\
0.69\end{array}$ & $\begin{array}{r}20.58 \\
1.22\end{array}$ & $\begin{array}{l}7.79 \\
0.35\end{array}$ & $\begin{array}{l}5.67 \\
0.43\end{array}$ & $\begin{array}{r}10.08 \\
0.65\end{array}$ & $\begin{array}{l}6.73 \\
0.73\end{array}$ \\
\hline
\end{tabular}

* Per cent of ash

$\dagger$ Difference between female and male has $p$ of $<0.2>0.1$. Combined mean $=9.68 \pm 0.55$ per cent. 
TABLE IV

Lipid composition of the ultrafiltrate (UFO), veronal soluble (RS1), and veronal insuluble (R1) fractions of normal urinary TNDS, expressed as per cent of dry weight of each fraction

\begin{tabular}{|c|c|c|c|c|c|c|c|c|}
\hline \multirow[b]{3}{*}{ Sample* } & \multirow[b]{3}{*}{ Fraction } & \multirow{3}{*}{$\begin{array}{l}\text { Total } \\
\text { lipidst }\end{array}$} & \multirow{3}{*}{$\begin{array}{c}\text { Total } \\
\text { phospho- } \\
\text { lipids } \ddagger\end{array}$} & \multirow{3}{*}{$\begin{array}{l}\text { Total } \\
\text { fatty } \\
\text { acids }\end{array}$} & \multicolumn{4}{|c|}{ Unsaponifiable } \\
\hline & & & & & \multirow[b]{2}{*}{ Total } & \multicolumn{3}{|c|}{ Cholesterol } \\
\hline & & & & & & Total & Free & Ester \\
\hline & $\begin{array}{l}R 1 \\
R S 1\end{array}$ & $\begin{array}{r}5.60 \\
15.10\end{array}$ & $\begin{array}{l}1.64 \\
3.27\end{array}$ & $\begin{array}{l}3.54 \\
3.74\end{array}$ & $\begin{array}{l}2.24 \\
4.79\end{array}$ & $\begin{array}{l}0.61 \\
1.02\end{array}$ & $\begin{array}{l}0.48 \\
0.74\end{array}$ & $\begin{array}{l}0.13 \\
0.28\end{array}$ \\
\hline \multirow[t]{3}{*}{ A } & weighted average $\S$ & 8.45 & 2.13 & 3.60 & 3.00 & 0.73 & 0.55 & 0.18 \\
\hline & $U F O$ & 1.01 & 0.08 & & 0.10 & & & \\
\hline & $\begin{array}{l}R 1 \\
R S 1\end{array}$ & $\begin{array}{l}11.15 \\
10.00\end{array}$ & $\begin{array}{l}2.82 \\
1.29\end{array}$ & $\begin{array}{l}4.91 \\
1.50\end{array}$ & $\begin{array}{l}1.50 \\
6.13\end{array}$ & $\begin{array}{l}1.09 \\
0.76\end{array}$ & $\begin{array}{l}0.74 \\
0.47\end{array}$ & $\begin{array}{l}0.35 \\
0.29\end{array}$ \\
\hline \multirow[t]{2}{*}{ B } & weighted average & 10.80 & 2.36 & 3.89 & 2.89 & 0.99 & 0.66 & 0.33 \\
\hline & $U F O$ & 0.43 & 0.05 & & 0.03 & & & \\
\hline
\end{tabular}

* Combined samples from several subjects.

$\dagger$ Weight of the chloroform extract.

+ Lipid $P \times 25$.

$\$$ Figures recalculated assuming average values of 0.7 and 0.3 for the ratios $R 1 / R O$ and $R S 1 / R O$, respectively.

in the $U F O$ fraction. The $R S 1$ fraction has onehalf per cent or less. None was detected in the $R 1$ fraction.

Paper electrophoresis with toluidine blue-O staining of the three fractions at $\mathrm{pH} 8.6$ revealed the consistent presence of material staining metachromatically in the UFO fraction. Although there was considerable "trailing," the migration of this material was similar to that of chondroitin sulfate. A very small quantity of material staining metachromatically and of similar mobility was usually evident in the $R S 1$ fraction. There was no metachromasia in any of the $R 1$ preparations.

\section{DISCUSSION}

The present report is concerned with the parametric composition and reproducibility of the fractions rather than with the identification of in-

\section{TABLE $\mathbf{V}$}

Some cations detected in ash of reronal insoluble (RI), veronal soluble (RS1) and ultrafiltrate (UFO) fractions of normal urinary TNDS

\begin{tabular}{lccccccc}
\hline \hline & & & & & & & \\
& $\mathrm{Al}$ & $\mathrm{Ni}$ & $\mathrm{Zn}$ & $\mathrm{Pb}$ & $\mathrm{Fe}^{+++}$ & $\mathrm{Fe}^{++}$ & $\mathrm{Mg}$ \\
\hline$R 1$ & $5 / 7^{*}$ & $9 / 9$ & $8 / 9$ & $6 / 6$ & $7 / 9$ & $5 / 9$ & $3 / 3$ \\
$R S 1$ & $0 / 6$ & $10 / 10$ & $9 / 10$ & $7 / 8$ & $3 / 11$ & $5 / 11$ & $3 / 3$ \\
UFO & $10 / 16$ & $16 / 16$ & $16 / 16$ & $15 / 16$ & $4 / 16$ & $11 / 16$ & $11 / 11$
\end{tabular}

* Number samples giving positive test per number of samples tested. dividual components of TNDS. The residue $R 1$ is composed of the Tamm and Horsfall mucoid ("uromucoid") $(10,11)$. The $R S 1$ fraction has been studied electrophoretically and includes serum proteins (12). The UFO consists of heterogeneous groups of molecules which include the "acid mucopolysaccharide" of Kerby (13) and Di Ferrante and Rich (14).

\section{Inorganic constituents}

The lack of a consistent calcium/phosphorus ratio in the various fractions is to be expected, since tests for inorganic phosphorus were nega-

TABLE VI

Average composition of veronal insoluble (RI), veronal soluble (RS1), and ultrafiltrate (UFO) fractions of normal urinary $T N D S$, expressed in per cent of dry weight

\begin{tabular}{lrrr}
\hline \hline & \multicolumn{1}{c}{$R$ RI } & \multicolumn{1}{c}{$R S 1$} & $U F O$ \\
\hline Hexuronic acid & & 0.50 & 1.33 \\
Hexosamine & 5.19 & 6.08 & 9.68 \\
Hexose* & 10.78 & 10.30 & 18.40 \\
Sialic acid & 3.52 & 6.09 & 10.55 \\
Protein† & 61.69 & 56.70 & 29.00 \\
Lipid & 8.37 & 12.55 & 0.72 \\
Ash & 4.84 & 5.88 & 20.58 \\
"Bound" water & 6.27 & 8.54 & 7.79 \\
Total & 100.66 & 106.64 & 98.05 \\
\end{tabular}

* Average of values obtained with anthrone and orcinol methods.

$\dagger \mathrm{N} \times 6.25$, corrected for $\mathrm{N}$ in sialic acid and hexosamine. 
TABLE VII

Rate of excretion for the constituents of three fractions of normal urinary TNDS, expressed as mg. per 24 hours

\begin{tabular}{|c|c|c|c|c|c|c|}
\hline \multirow{2}{*}{$\begin{array}{l}\text { Constituent } \\
\text { Total } \\
\text { Hexuronic acid }\end{array}$} & \multirow{2}{*}{$\begin{array}{c}\text { Mean } R I^{*} \\
89.6\end{array}$} & \multirow{2}{*}{$\frac{ \pm \text { S. E. } R I}{11.42}$} & \multicolumn{2}{|c|}{ Mean $R S 1^{*} \pm$ S. E. $R S 1$} & \multicolumn{2}{|c|}{ Mean $U F O^{*} \pm$ S. E. $U F O$} \\
\hline & & & 58.8 & 7.34 & $\begin{array}{l}264.5 \\
3.55\end{array}$ & $\begin{array}{r}29.17 \\
0.84\end{array}$ \\
\hline $\begin{array}{l}\text { Hexosamine } \\
\text { (female) }\end{array}$ & 4.50 & 0.97 & 4.02 & 1.00 & 17.20 & 0.78 \\
\hline $\begin{array}{l}\text { Hexosamine } \\
\text { (male) }\end{array}$ & $4.71 f$ & 0.70 & $3.11 \dagger$ & 0.36 & $31.0 \dagger$ & 2.83 \\
\hline $\begin{array}{l}\text { Hexosamine } \\
\text { (female and male) }\end{array}$ & 4.63 & 0.55 & 3.49 & 0.46 & & \\
\hline $\begin{array}{l}\text { Hexose (anthrone) } \\
\text { Hexose (orcinol) } \\
\text { Sialic acid } \\
\text { Ash } \\
\text { "Bound" water } \\
\text { Nitrogen } \\
\text { Calcium } \\
\text { Phosphorus }\end{array}$ & $\begin{array}{r}13.03 \\
7.23 \\
3.38 \\
4.58 \\
5.75 \\
9.44 \\
0.44 \\
3.95\end{array}$ & $\begin{array}{l}2.08 \\
1.11 \\
0.31 \\
2.32 \\
0.67 \\
1.15 \\
0.11 \\
0.89\end{array}$ & $\begin{array}{l}7.70 \\
5.02 \\
3.38 \\
3.54 \\
5.02 \\
5.82 \\
0.23 \\
0.43\end{array}$ & $\begin{array}{l}1.25 \\
0.67 \\
0.69 \\
0.57 \\
0.90 \\
0.71 \\
0.06 \\
0.09\end{array}$ & $\begin{array}{r}51.36 \\
39.94 \\
28.93 \\
53.60 \\
21.33 \\
15.22 \\
5.10 \\
3.95\end{array}$ & $\begin{array}{l}7.63 \\
4.23 \\
4.49 \\
5.95 \\
3.12 \\
3.71 \\
0.33 \\
0.89\end{array}$ \\
\hline
\end{tabular}

* R1: veronal insoluble fraction. $R S 1$ : veronal soluble fraction. $U F O$ : Ultrafiltrate.

$\dagger \mathrm{p}$ for difference between female and male for $R 1$ : $<0.9>0.8$, for $R S 1$ : $<0.5>0.3$, for $U F O:<0.01>0.001$.

tive prior to ashing the samples. The presence of metal ions found are probably adventitious, atthose cations indicated in Table $\mathrm{V}$ were specifically tributable to the metal-binding capacity of prodemonstrated by the spot tests and confirmed in teinaceous materials present in the fractions. The most instances by spectrography. Tests for cop- absence of copper suggests that ceruloplasmin is per and manganese were negative. The heavy- not a prominent constituent of the TNDS.

TABLE VIII

Comparison of per cent composition of three fractions of normal urinary TNDS

\begin{tabular}{|c|c|c|c|c|c|c|c|c|c|c|c|c|}
\hline \multirow[b]{2}{*}{ Constituent } & \multirow[b]{2}{*}{$\underset{R_{I^{*}}}{\text { Number }}$} & \multirow[b]{2}{*}{$\underset{R I}{\text { Mean }}$} & \multirow[b]{2}{*}{$\underset{R S I^{*}}{\text { Number }}$} & \multirow[b]{2}{*}{$\underset{R S 1}{\text { Mean }}$} & \multirow[b]{2}{*}{$\begin{array}{l}\text { Number } \\
\text { UFO* }\end{array}$} & \multirow[b]{2}{*}{$\begin{array}{c}\text { Mean } \\
\text { UFO }\end{array}$} & \multicolumn{6}{|c|}{ Statistical comparisons } \\
\hline & & & & & & & $\begin{array}{c}\mathrm{t}_{1} \\
R 1 \\
\text { with } \\
R S 1\end{array}$ & $\begin{array}{l}\mathbf{p} \\
t_{1}\end{array}$ & $\begin{array}{c}\mathrm{t}_{2} \\
U^{\prime} O \\
\text { with } \\
R S 1\end{array}$ & $\begin{array}{l}p \\
t_{2}\end{array}$ & $\begin{array}{c}\mathrm{tz}_{\mathbf{3}} \\
U_{\text {with }} \\
\text { w1 }\end{array}$ & $\underset{t_{3}}{p}$ \\
\hline $\begin{array}{c}\text { Hexosamine } \\
\text { (female) }\end{array}$ & (5) & 4.14 & (5) & 6.16 & (5) & 8.66 & $\dagger$ & & & & & \\
\hline$\underset{\text { (male) }}{\text { Hexosamine }}$ & (7) & 6.24 & (7) & 6.03 & (7) & 10.41 & $t$ & & & & & \\
\hline $\begin{array}{l}\text { Hexosamine } \\
\text { (female and male) }\end{array}$ & & & (12) & 6.08 & (12) & 9.68 & & & 4.836 & 0.001 & & \\
\hline Hexose (anthrone) & (9) & 13.52 & (8) & 11.96 & (9) & 21.59 & 1.248 & $\begin{array}{l}<0.3 \\
>0.2\end{array}$ & 3.310 & $\begin{array}{l}<0.01 \\
>0.001\end{array}$ & 3.028 & $\begin{array}{l}<0.01 \\
>0.001\end{array}$ \\
\hline Hexose (orcinol) & (12) & 8.03 & (12) & 8.63 & (12) & 15.20 & 0.724 & $\begin{array}{l}0.5 \\
0.3\end{array}$ & 7.491 & 0.001 & 8.905 & 0.001 \\
\hline Hexose (anth./orc.) & (9) & 1.800 & (8) & 1.381 & (9) & 1.40 & 2.940 & $\begin{array}{l}0.02 \\
0.01\end{array}$ & 0.127 & 0.9 & 2.076 & $\begin{array}{l}0.1 \\
0.05\end{array}$ \\
\hline Sialic acid & (12) & 3.52 & (12) & 6.09 & (12) & 10.55 & 1.682 & $\begin{array}{l}0.2 \\
0.1\end{array}$ & 3.168 & $\begin{array}{l}0.01 \\
0.001\end{array}$ & 5.004 & 0.001 \\
\hline Ash & (11) & 4.84 & (11) & 5.88 & (12) & 20.58 & 1.337 & $\begin{array}{l}0.2 \\
0.1\end{array}$ & 10.131 & 0.001 & 12.024 & 0.001 \\
\hline "Bound" water & (11) & 6.27 & (11) & 8.54 & (12) & 7.79 & 2.333 & $\begin{array}{l}0.05 \\
0.02\end{array}$ & 0.770 & $\begin{array}{l}0.5 \\
0.3\end{array}$ & 3.665 & $\begin{array}{l}0.01 \\
0.001\end{array}$ \\
\hline Nitrogen & (12) & 10.35 & (12) & 9.72 & (10) & 5.67 & 2.100 & 0.05 & 9.330 & 0.001 & 9.811 & 0.001 \\
\hline Calcium & (11) & 9.09 & (11) & 7.27 & (12) & 10.08 & 0.759 & $\begin{array}{l}0.5 \\
0.3\end{array}$ & 1.896 & $\begin{array}{l}0.1 \\
0.05\end{array}$ & 0.497 & $\begin{array}{l}0.7 \\
0.6\end{array}$ \\
\hline Phosphorus & (11) & 21.30 & (11) & 15.55 & (12) & 6.73 & 1.090 & 0.3 & 2.170 & $\begin{array}{l}0.05 \\
0.02\end{array}$ & 5.038 & 0.001 \\
\hline
\end{tabular}

* R1: veronal insoluble fraction. RS1: veronal soluble fraction. UFO: Ultrafiltrate.

* R1: veronal insoluble fraction. $R S 1$ : veronal soluble fraction. UFO: Ultrafiltrate.
+ For $R 1$ the probability $(\mathrm{p})$ for the difference between female and male $=<0.001$. Therefore no comparison was run with $R S 1$. 


\section{Protides}

When the nitrogen content of each fraction is corrected for the nitrogen content of hexosamine and sialic acid and then multiplied by the factor 6.25 , the $R 1, R S 1$ and $U F O$ are shown to contain 55,33 and $77 \mathrm{mg}$. per day of protein material, respectively. Correction of this sum for the overall loss of 18 per cent incurred during fractionation gives a protein excretion of $201 \mathrm{mg}$. per 24 hours, which is in agreement with the previously determined (1) value of $204 \mathrm{mg}$. per 24 hours for the TNDS.

It is of interest that the TNDS account for less than one-third of the total "bound" amino acids of human urine (15-17). It would appear that twothirds of the "bound" amino acids of normal urine are of such dimensions as to be dialyzable through cellophane membranes.

\section{Glucides}

Since a chondroitin sulfate has been found in urine $(13,14)$, the results obtained by the two methods, taken together, indicate the presence of one or more nondialyzable hexuronic acid conjugates other than chondroitin sulfate.

\section{Lipids}

The lipids represent only a small portion of the dry weight of the ultrafiltrate (1 per cent or less). On the other hand, the total nonultrafiltrable residue contains sizeable amounts of lipids (as much as 10 per cent). A recalculation of the values of this material indicates a lipid composition very similar in the two pooled samples which were analyzed. In both samples, all types of lipids are distributed between the $R 1$ and the $R S 1$ fractions. However, the distribution of the individual lipids in sample $A$ is quantitatively rather different from that found in sample B. ${ }^{8}$

8 The separation of the $R 1$ and $R S 1$ fractions prior to the lipid analysis has been carried out on pooled samples of $R O$ which had been preserved in the frozen state. It cannot be excluded that some splitting of the linkages between the protein and lipid moieties of lipoproteins might have occurred during the freezing and thawing of these samples, and that this might account, in part at least, for the differences observed (18) between samples $A$ and. $B$.

\section{Comparison of the composition of the three frac- tions}

Referring to Table VIII, one will note certain differences in the percentage composition of the three fractions which are significant if one accepts a probability of $<0.05$. The hexosamine constant of $R 1$ was significantly less in females, whereas there was no sex difference in either $R S 1$ or UFO. The ratio for hexose (orcinol/anthrone) in $R 1$ was significantly greater than in $R S 1$. The "bound" water content of RSI was greater than for $R 1$, while the nitrogen content of $R 1$ exceeded that for $R S 1$. Also, it will be seen that $U F O$ differs significantly from $R S 1$ and $R 1$ except with respect to the hexose ratio, "bound" water, and calcium for the former and hexose ratio and calcium for the latter.

Two additional observations made during this work may be useful to other workers.

First, concentration of UFO by dialysis through Visking cellulose tubing against concentrated polyvinylpyrrolidone $^{2}$ or polyethylene glycol ${ }^{10}$ was not satisfactory, since a small but significant proportion of the polymer passed through the membrane and became mixed with the sample.

Second, in experiments with two specimens, lyophilization of TNDS was found to cause 69 and 48 per cent of it to become dialyzable. The material which passed through the cellophane was strongly ninhydrin positive, did not contain sialic acid or hexose, and was a hygroscopic gum on relyophilization. The major contributor to this loss is the UFO fraction, since, when lyophilized samples of the three fractions were similarly checked, the percentages of the starting weights lost by dialysis were respectively 83, 3 and 6 for $U F O, R S 1$ and $R 1$. Moreover, the naphthoresorcinol-determined hexuronic acid (but not that determined with carbazole, which was correspondingly concentrated), part of the hexose and of the sialic acid was dialyzable from the UFO, showing that the fractions may not behave in a manner comparable to the TNDS under these conditions. These observations demonstrate that lyophilization may have drastic effects on these materials and that redialysis may result in loss.

\footnotetext{
9 Plasdone C@, Antara Chemicals, General Aniline and Film Corp.

10 Carbowax 60006, Union Carbide Chemicals Co.
} 


\section{SUM MARY}

A method has been described for the separation of urinary total nondialyzable solids (TNDS) into three reproducible fractions. The 24 hour excretion rates and the overall chemical composition of these three fractions is presented.

\section{ACKNOWLEDGMENT}

The authors wish to express their appreciation to Mrs. Phyllis Tilley, Miss Emily Angell and Miss Nell Williams for technical assistance.

\section{REFERENCES}

1. King, J. S., Jr., Boyce, W. H., Little, J. M., and Artom, C. Total nondialyzable solids (TNDS) in human urine. I. The amount and composition of TNDS from normal subjects. J. clin. Invest. 1958, 37, 315.

2. Feigl, F. Qualitative Analysis by Spot Tests. New York, Nordeman Publishing Co., 1939, p. 83.

3. Schloss, B. Colorimetric determination of glucosamine. Analyt. Chem. 1951, 23, 1321.

4. DeFrates, J. S., and Boyd, M. J. Microdetermination of glucuronic acid in blood. Fed. Proc. 1953, $12,194$.

5. Dische, Z. A new specific color reaction of hexuronic acids. J. biol. Chem. 1947, 167, 189.

6. Shetlar, M. R., and Shetlar, C. L. Determination of hexuronic acid in biological material. Fed. Proc. 1958, 17, 310.

7. Di Ferrante, N., and Rich, C. The mucopolysaccharide of normal human urine. Clin. chim. Acta 1956, 1, 519.

8. Bloor, W. R. The determination of cholesterol in blood. J. biol. Chem. 1916, 24, 227.
9. King, J. S., Jr., and Hyder, N. A glucosamine conjugate occurring in human urine. Proc. Soc. exp. Biol. (N. Y.) 1955, 89, 342.

10. Tamm, I., and Horsfall, F. L., Jr. Characterization and separation of an inhibitor of viral hemagglutination present in urine. Proc. Soc. exp. Biol. (N. Y.) 1950, 74, 108.

11. Boyce, W. H., and Swanson, M. Biocolloids of urine in health and in calculous disease. II. Electrophoretic and biochemical studies of a mucoprotein insoluble in molar sodium chloride. J. clin. Invest. 1955, 34, 1581.

12. Boyce, W. H., Garvey, F. K., and Norfleet, C. M., Jr. Proteins and other biocolloids of urine in health and in calculous disease. I. Electrophoretic studies at $\mathrm{pH} 4.5$ and 8.6 of those components soluble in molar sodium chloride. J. clin. Invest. 1954, 33, 1287.

13. Kerby, G. P. The excretion of glucuronic acid and of acid mucopolysaccharides in normal human urine. J. clin. Invest. 1954, 33, 1168.

14. Di Ferrante, N., and Rich, C. The determination of acid aminopolysaccharide in urine. J. Lab. clin. Med. 1956, 48, 491.

15. Eades, C. H., Jr., and Pollack, R. L. Urinary excretion of fourteen amino acids by normal and cancer subjects. J. nat. Cancer Inst. 1954, 15, 421.

16. Artom, C. Determinazione comparativa degli aminoacidi e dei polipeptidi nell'urina. Boll. Soc. ital. Biol. sper. 1929, 4, 868.

17. Stein, W. H., and Carey, G. C. A chromatographic investigation of the amino acid constituents of normal urine. J. biol. Chem. 1953, 201, 45.

18. Oncley, J. L., Gurd, F. R. N., and Melin, M. Preparation and properties of serum and plasma proteins. XXV. Composition and properties of human serum $\beta$-lipoproteins. J. Amer. chem. Soc. 1950, 72, 458. 